\title{
HEMATOLOGIS BEBERAPA SPESIES IKAN LAUT BUDI DAYA
}

\author{
Fris Johnny, Zafran, Des Roza, dan Ketut Mahardika
}

\begin{abstract}
ABSTRAK
Suatu percobaan dengan tujuan mendapatkan keragaan hematologis beberapa jenis ikan laut budi daya telah dilakukan. Ikan uji yang digunakan adalah ikan bandeng (Chanos chanos Forskal), kakap putih (Lates calcarifer), napoleon (Cheilinus undulates), kerapu lumpur (Epinephelus coioides), kerapu macan (Epinephelus fuscoguttatus), dan kerapu bebek (Cromileptes altivelis). Semua ikan uji yang diamati, selain ikan napoleon diperoleh dari hasil budidaya. Ikan napoleon diperoleh dari alam, setelah dikondisikan pada panti benih selama sekitar delapan minggu, selanjutnya digunakan sebagai ikan uji. Pengamatan dilakukan terhadap penetapan nilai hematokrit, kadar hemoglobin, total eritrosit, total leukosit, dan diferensial leukosit. Hasil percobaan menunjukkan nilai hematokrit tertinggi pada ikan bandeng sebesar 37,5\% dan terendah pada ikan kerapu bebek sebesar 26,0\%. Kadar hemoglobin tertinggi pada ikan kakap putih sebesar $9,5 \mathrm{~g} / 100 \mathrm{~mL}$ dan terendah pada ikan kerapu bebek sebesar $5,5 \mathrm{~g} / 100 \mathrm{~mL}$. Total eritrosit tertinggi pada ikan kerapu macan sebesar $3,35 \times 10^{6} \mathrm{sel} / \mathrm{mL}$, dan terendah pada ikan kerapu bebek sebesar 1,84 × $10^{6} \mathrm{sel} / \mathrm{mL}$. Total leukosit tertinggi pada ikan kakap putih sebesar $183,5 \times 10^{3} \mathrm{sel} / \mathrm{mL}$, dan terendah pada ikan kerapu bebek sebesar $35,2 \times 10^{3} \mathrm{sel} / \mathrm{mL}$. Sedangkan untuk diferensial leukosit; persentase neutrofil tertinggi pada ikan kakap putih sebesar $8,0 \%$, dan terendah pada ikan kerapu lumpur sebesar 3,9\%. Persentase monosit tertinggi pada ikan kerapu lumpur sebesar $2,5 \%$ dan terendah pada ikan kerapu bebek sebesar 1,3\%. Persentase limfosit tertinggi pada ikan kerapu lumpur sebesar $25,0 \%$ dan terendah pada ikan napoleon sebesar $13,2 \%$. Persentase trombosit tertinggi pada ikan napoleon sebesar $78,1 \%$ dan terendah pada ikan kerapu lumpur sebesar 68,3\%.
\end{abstract}

\section{ABSTRACT: Hematology of several species of maricultured fish. By: Fris Johnny, Zafran, Des Roza, and Ketut Mahardika}

The aim of this research was to know the hematocrit, hemoglobin, total erytrocyte, total leucocyte, and differential leucocyte feature in maricultured fish blood. Maricultured fish used were milkfish (Chanos chanos Forskal), barramundi (Lates calcarifer), napoleonfish (Cheilinus undulatus), orangespotted grouper (Epinephelus coioides), tiger grouper (Epinephelus fuscoguttatus), dan humpback grouper (Cromileptes altivelis). The results showed that hematocrit value of highes on milkfish were $37.5 \%$ and lowest on orangespotted grouper were $26.0 \%$. Hemoglobin values of highes on barramundi were $9.5 \mathrm{~g} / 100 \mathrm{~mL}$, and lowest on humpback grouper were $5.5 \mathrm{~g} / 100 \mathrm{~mL}$. Total erytrocytes value of highes on tiger grouper were $3.35 \times 10^{6} \mathrm{ce} / / \mathrm{s} /$ $\mathrm{mL}$, and lowest on humpback grouper were $1.84 \times 10^{6} \mathrm{cells} / \mathrm{mL}$. Tolal leucocytes of highes on barramundi were $183.5 \times 10^{3} \mathrm{cel} / \mathrm{s} / \mathrm{mL}$, and lowest on humpback grouper were $35.2 \times 10^{3} \mathrm{cells} /$ $m L$. Differential leucocytes value of neutrophy highes on barramundi were $8.0 \%$ (I) and lowest on orangespotted grouper were $3.9 \%$. Value of monocyte highes on orangespotted grouper were $2.5 \%$ and lowest on humpback grouper were 1.3\%. Value of ymphocyte highes on orangespotted grouper were $25.0 \%$ and lowest on napoleon were $13.2 \%$. And value of trombocyte on napoleon were $78.1 \%$ and lowest on orangespotted grouper were $68.3 \%$.

KEYWORDS: $\quad$ hematology, mariculture, marinefish

\section{PENDAHULUAN}

Pembenihan dan budi daya beberapa jenis ikan laut di Indonesia sudah semakin berkembang, baik di tambak maupun di keramba jaring apung. Beberapa spesies ikan laut yang telah dibudidayakan adalah ikan bandeng, Chanos chanos Forskal; ikan kakap putih, Lates calcarifer; ikan kerapu bebek, Cromileptes altivelis; ikan kerapu macan, Epinephelus fuscoguttatus; dan ikan kerapu Lumpur, Epinephelus coioides (Sukadi, 2002).

Saat ini, kebutuhan benih sudah dapat dipenuhi dari panti benih, dan tidak lagi mengandalkan pasok alam. Namun, dalam usaha pembenihan secara

Peneliti pada Balai Besar Riset Perikanan Budidaya Laut, Gondol 
intensif dan terkontrol masih ditemukan beberapa kendala, antara lain masin tingginya angka kematian baik pada stadia larva maupun tingkat benih. Salah satu penyebab kematian diduga akibat infeksi penyakit (Johnny \& Roza, 2002)

Hematologi merupakan disiplin ilmu yang mempelajari komponen sel darah serta kelainan fungsional dari sel tersebut. Selain itu juga mempelajari volume darah, sifat aliran darah, dan hubungan fisik antara sel-sel darah dan plasma. Hematologi sangat berhubungan dengan patologi, terutama untuk memperoleh gambaran kondisi kesehatan ikan apakah dalam keadaan sehat atau sakit. Sel darah mempunyai peran sangat penting dalam sistem kekebalan, terutama leukosit atau sel darah putih. Jenis-jenis leukosit mempunyai beberapa fungsi dalam melawan benda asing yang berhasil masuk ke dalam tubuh. Darah dianggap sebagai jaringan khusus yang menjalani sirkulasi, terdiri atas berbagai macam sel yang terkandung dalam cairan yang disebut plasma. Aliran darah dalam saluran tubuh menjamin lingkungan yang tetap agar semua sel serta jaringan mampu melaksanakan fungsinya. Darah ikan terdiri atas eritrosit atau sel darah merah dan leukosit atau sel darah putih. Pada ikan, leukosit terdiri atas neutofil, monosit, limfosit, dan trombosit dengan peranan serta fungsi yang berbeda. Fungsi darah dalam sirkulasi adalah sebagai media transportasi bahan dan sisa metabolisme, pengatur suhu, dan pemelihara keseimbangan cairan, asam, dan basa. Secara rinci fungsi darah adalah: 1) membawa zat makanan yang telah disiapkan oleh saluran pencernaan menuju ke jaringan tubuh, 2) membawa oksigen ke jaringan, 3) membawa karbondioksida dari jaringan, 4) membawa produk buangan dari berbagai jaringan untuk diekskresikan, 5) membawa hormon dari kelenjar endokrin ke organ lain, 6) berperan penting dalam pengendalian suhu tubuh, 7) berperan dalam mempertahankan keseimbangan air, 8) berperan dalam system buffer untuk membantu mempertahankan $\mathrm{pH}, 9$ ) penggumpalan atau pembekuan darah sehingga dapat mencegah terjadinya kehilangan darah yang berlebihan pada waktu luka, dan 10) mengandung berbagai faktor penting untuk mempertahankan tubuh dari serangan penyakit (Anderson, 1974; Schalm et al., 1975; Tizard, 1982; Manning \& Tatner, 1985; Post, 1987; Schubert, 1987; Andrew et al., 1988; Moyle \& Cech, 1988; Chinabut et al., 1991; Brown, 1993; Klontz, 1994; Anderson \& Siwicki, 1995; Iwama \& Nakanishi, 1996).

Pemeriksaan darah sangat perlu terutama pada keadaan patologis tertentu. Hasilnya bisa digunakan sebagai pelengkap diagnosis. Pemeriksaan sel-sel darah biasanya dilakukan melalui preparat ulas dan secara diagnostik penghitungan sel darah sangat berarti (Nabib \& Pasaribu, 1989). Namun demikian susunan sel-sel darah sangat bervariasi antar spesies ikan (Filho et al., 1992; Singh \& Banerjee, 1992; Tochilina, 1992; Yamamoto \& lida, 1994).

Darah ikan terdiri atas plasma darah dan sel darah. Berdasarkan warnanya sel darah dibagi menjadi sel darah merah (eritrosit) dan sel darah putih (leukosit). Eritrosit ikan tidak seperti halnya mamalia, eritrosit ikan mempunyai inti yang berbentuk elips, terletak di tengah sel dan dengan pewarnaan giemsa berwarna ungu kebiruan. Sitoplasma eritrosit tampak beraspek translusen, kadang-kadang berwarna kekuningan dan terlihat mengandung butir-butir halus berwarna merah, terutama pada ikan yang lebih tua. Eritrosit merupakan jenis sel darah yang paling umum, sekitar $60 \%$ volume eritrosit terdiri atas air dan sisanya $40 \%$ terdiri atas konjugasi protein yang berbentuk globin dan hem. Pigmen yang merupakan $4 \%$ dari konjugasi protein disebut hemoglobin, pigmen ini memberikan warna merah pada darah segar. Eritrosit mempunyai peranan utama sebagai pengangkut oksigen dalam tubuh (Schalm et al., 1975; Post, 1987; Schubert, 1987; Andrew et al., 1988; Moyle \& Cech, 1988; Nabib \& Pasaribu, 1989; Chinabut et al., 1991; Brown, 1993; Klontz, 1994; Anderson \& Siwicki, 1995); dan ukuran eritrosit antar spesies juga berbeda (Yamamoto \& lida, 1994).

Pada ikan laut yang sudah dibudidayakan, belum banyak dilaporkan mengenai gambaran hematologis. Beberapa gambaran hematologis ikan laut budi daya yang telah diamati antara lain: ikan kerapu bebek, Cromileptes altivelis (Johnny et al., 1999); ikan napoleon, Cheilinus undulates (Johnny et al., 2001); dan ikan kakap putih, Lates calcarifer (Johnny, 2002). Pengaruh vitamin $\mathrm{C}$ dalam pakan terhadap perubahan hemositologis ikan kerapu bebek telah dilaporkan oleh Johnny et al. (2002). Percobaan ini bertujuan untuk mendapatkan data tentang gambaran hematologis beberapa ikan budi daya laut.

\section{BAHAN DAN METODE}

\section{Ikan Uji}

Semua ikan uji yang diamati selain ikan napoleon, diperoleh dari hasil budi daya. Ikan napoleon diperoleh dari alam dengan bobot sekitar $100 \mathrm{~g}$, dan setelah dikondisikan pada panti benih selama sekitar delapan minggu, selanjutnya digunakan sebagai ikan uji. Semua ikan uji yang diamati dalam kondisi sehat. Pengamatan hematologis beberapa ikan budi daya laut dilakukan berdasarkan modifikasi dari metode Klontz (1994) dan Anderson \& Siwicki (1995). Peubah yang diamati adalah pola gambaran hematologis yang meliputi: penetapan nilai hematokrit, penetapan kadar 
hemoglobin, penghitungan total eritrosit, penghitungan total leukosit, dan persentase diferensial leukosit. Data hasil percobaan ini dievaluasi secara deskriptif.

\section{Koleksi Darah Ikan}

Setelah masa aklimasi ikan uji dimasukkan ke dalam wadah fiber volume $20 \mathrm{~L}$ berisikan 10 liter air laut yang telah berisikan bahan pembius FA-100 produksi Tanabe Seiyaku, Jepang dengan dosis $1 \mathrm{cc} /$ 5 I. Setelah ikan uji pingsan, sampel darah disedot dengan spuit plastik steril volume $1 \mathrm{cc}$ yang di dalamnya telah berisikan antikoagulan Heparin Leo produksi Pharmaceutical, Denmark melalui vena jugularis sebanyak 0,5 cc. Selanjutnya koleksi darah disimpan dalam box styrofoam berisikan es, dan siap digunakan untuk uji-uji hematologi.

\section{Penetapan Nilai Hematokrit (PCV)}

Sampel darah yang telah dikoleksi, disedot dengan tabung kapiler untuk pengamatan hematokrit. Kemudian tabung kapiler tersebut dipusing pada sentrifus dengan kecepatan $12.000 \mathrm{rpm}$ selama 5 menit dan selanjutnya dihitung persentase hematokrit dengan alat pengukur. Alat yang dipakai untuk mengukur nilai hematokrit disebut dengan tabung hematokrit. Sebagian besar volume padat dari darah terdiri atas eritrosit, hematokrit disebut juga dengan nama lain sebagai packed cell volume yaitu; volume semua eritrosit dalam $100 \mathrm{~mL}$ darah dan dinyatakan dalam \% dari volume darah itu, serta disingkat dengan PCV. Nilai hematokrit adalah volume yang diisi oleh eritrosit, dinyatakan sebagai persen terhadap volume total contoh darah itu.

\section{Penetapan Kadar Hemoglobin (Hb)}

Sampel darah diteteskan pada blood chamber $\mathrm{Hb}$ meter lalu diaduk dengan menggunakan hemolysis applicators yang mengandung $10 \mathrm{mg}$ sodium oxalate dan $200 \mathrm{mg}$ saponin. Setelah teraduk rata dengan menggunakan alat hemoglobinometer "IMI" produksi Jepang, dilakukan penetapan kadar hemoglobin. Hemoglobin itu sendiri merupakan senyawa yang terdiri atas: protoforfirin, globin, dan zat besi ( $\mathrm{Fe})$. Kadar hemoglobin dalam darah dinyatakan dalam gram $\mathrm{Hb} /$ $100 \mathrm{~mL}$.

\section{Penghitungan Total Eritrosit}

Dari koleksi sampel darah, dengan menggunakan pipet pengencer eritrosit sampel darah disedot sampai skala 0,5 dan dilanjutkan dengan penyedotan larutan Rees-Ecker (sodium citrate, formalin 37\%--40\%, dan brilliant cresyl blue) sampai skala 101 (Klontz, 1994). Kemudian diaduk rata dengan cara membentuk angka 8 di udara selama 3 menit. Setelah teraduk rata didiamkan dulu selama 3 menit. Sebelum dimasukkan ke alat penghitung eritrosit improved neubauer sampel dibuang dulu dengan menggunakan tisu, karena pada bagian ujung pipet hanya berisikan larutan pengencer. Selanjutnya dimasukkan ke improved neubauer dan sisa luberan pada kaca penutup disedot dengan kertas saring, didiamkan selama 3 menit, lalu eritrosit dihitung pada mikroskop dengan pembesaran 40x.

Alat yang digunakan untuk penghitungan total eritrosit adalah "Hemositometer" dengan menggunakan kamar-kamar hitung improved neubauer, prinsipnya adalah menghitung distribusi eritrosit pada kamar hitung. Untuk penghitungan eritrosit adalah dengan menggunakan ruang kecil di tengah-tengah improved neubauer sebanyak 25 ruang; dari 25 ruang kecil yang dihitung adalah pada ruang keempat sudut ditambah ruang tengah.

\section{Penghitungan Total Leukosit}

Dari koleksi sampel darah, dengan menggunakan pipet pengencer leukosit sampel disedot sampai skala 0,5 dan dilanjutkan dengan penyedotan larutan ReesEcker sampai skala 11. Tahapan selanjutnya sama dengan penghitungan eritrosit.

Tabel 1. Ikan laut budi daya

Table 1. Maricultured fish

\begin{tabular}{lcc}
\hline \multicolumn{1}{c}{$\begin{array}{c}\text { Nama dan jenis ikan } \\
\text { Fish name and species }\end{array}$} & $\begin{array}{c}\text { Bobot badan } \\
\text { Body weight } \\
\text { (g) }\end{array}$ & $\begin{array}{c}\text { Panjang total } \\
\text { Total length } \\
\text { (cm) }\end{array}$ \\
\hline Bandeng (Milkfish), Chanos chanos Forskal & $105--215$ & $18--23$ \\
Kakap putih (Barramundi), Lates calcarifer & $131-236$ & $21.5--25.5$ \\
Napoleon (Napoleon fish), Cheilinus undulatus & $216-451$ & $24--32$ \\
Kerapu lumpur (Orangespotted grouper), Epinephelus coioides & $115-185$ & $17--21$ \\
Kerapu macan (Tiger grouper), Epinephelus fuscoguttatus & $95--125$ & $16--19$ \\
Kerapu bebek (Humpback grouper), Cromileptes altivelis & $125-200$ & $20.5-22.5$ \\
\hline
\end{tabular}


Untuk penghitungan leukosit adalah dengan menggunakan ruang besar di sebelah luar ruang kecil pada improved neubauer yang berjumlah 16 ruang pada satu lokasi; dari 4 lokasi, total ruang besar adalah sebanyak 64 ruang, dan penghitungan leukosit dilakukan pada semua ruang besar.

\section{Total eritrosit $=$}

\section{5 area $\times 10 \times 5 \times 200$ atau $\mathrm{n} \times 10^{4} / \mathrm{mm}^{3}$}

dengan nilai $n$ adalah jumlah total 5 area penghitungan ruang kecil

\section{Penghitungan Persentase Diferensial Leukosit}

Dari satu tetes darah kemudian dibuat preparat darah ulas tipis pada gelas objek, kemudian segera dikeringkan dengan cara mengibas-ibaskan di udara. Setelah kering dilakukan pewarnaan May Gruenwald'sGyemsa. Larutan May-Gruenwald's diteteskan sampai menutupi permukaan sampel untuk fiksasi, didiamkan selama 1 menit. Akuades kemudian diteteskan pada sampel sampai larutan May-Gruenwald's melayanglayang, secara pelan-pelan ditiup sampai tercampur rata, dan didiamkan selama 3 menit. Kemudian dicuci dengan akuades, dan dicat dengan pewarnaan

Total leukosit =

\section{4 area $\times 200 \times 10 / \mathrm{mm}^{3}$}

\section{4}

Gyemsa 3\% (Gyemsa $3 \mathrm{~mL}$ dan air kran $97 \mathrm{~mL}$, selalu dibuat baru sebelum pewarnaan) dengan jalan meneteskan bahan tersebut pada permukaan gelas objek sampai menutupi sampel. Kemudian didiamkan selama 30--40 menit. Selanjutnya dicuci dengan akuades, dan dikeringkan selama satu hari. Setelah kering kemudian direndam dalam xylol selama 5 menit, dan ditutup dengan menggunakan bioleit. Sediaan diamati pada mikroskop dengan pembesaran 40x untuk menentukan persentase jenis leukosit yaitu; neutrofil, limfosit, monosit, dan trombosit.

\section{HASIL DAN BAHASAN}

\section{Penetapan Nilai Hematokrit (PCV)}

Dari Gambar 1, penetapan nilai hematokrit dari beberapa jenis ikan budi daya laut berturut-turut adalah pada ikan bandeng sebesar $37,5 \%$; ikan kerapu macan sebesar $31,5 \%$; ikan kerapu lumpur sebesar $30,5 \%$; ikan kakap putih sebesar $28,75 \%$; ikan napoleon sebesar $28 \%$; dan ikan kerapu bebek sebesar $26 \%$. Melihat hasil penetapan nilai hematokrit yang diperoleh dalam percobaan, hematokrit masih berada dalam kisaran normal seperti yang telah dilaporkan oleh Ikeda et al. (1986) pada ikan yellowtail sebesar 42,9\%. Dan menurut Klontz (1994), pada ikan common carp sebesar 26\%--39\% dan ikan rainbow trout sebesar $13 \%--42 \%$.

Apabila pada hewan terjadi perubahan pada karakteristik darahnya, dapat diduga hewan tersebut mengalami suatu infeksi atau terekspose pada suatu kondisi yang membuat ikan menjadi stres. Parameter hematokrit berpengaruh terhadap pengukuran eritrosit dan merupakan perbandingan antara plasma darah dengan volume eritrosit (Schalm et al., 1975; Klontz, 1994; Anderson \& Siwicki, 1995). Apabila ikan terkena infeksi penyakit atau nafsu makan menurun, nilai hematokrit menjadi rendah (Bastiawan et al., 2001).

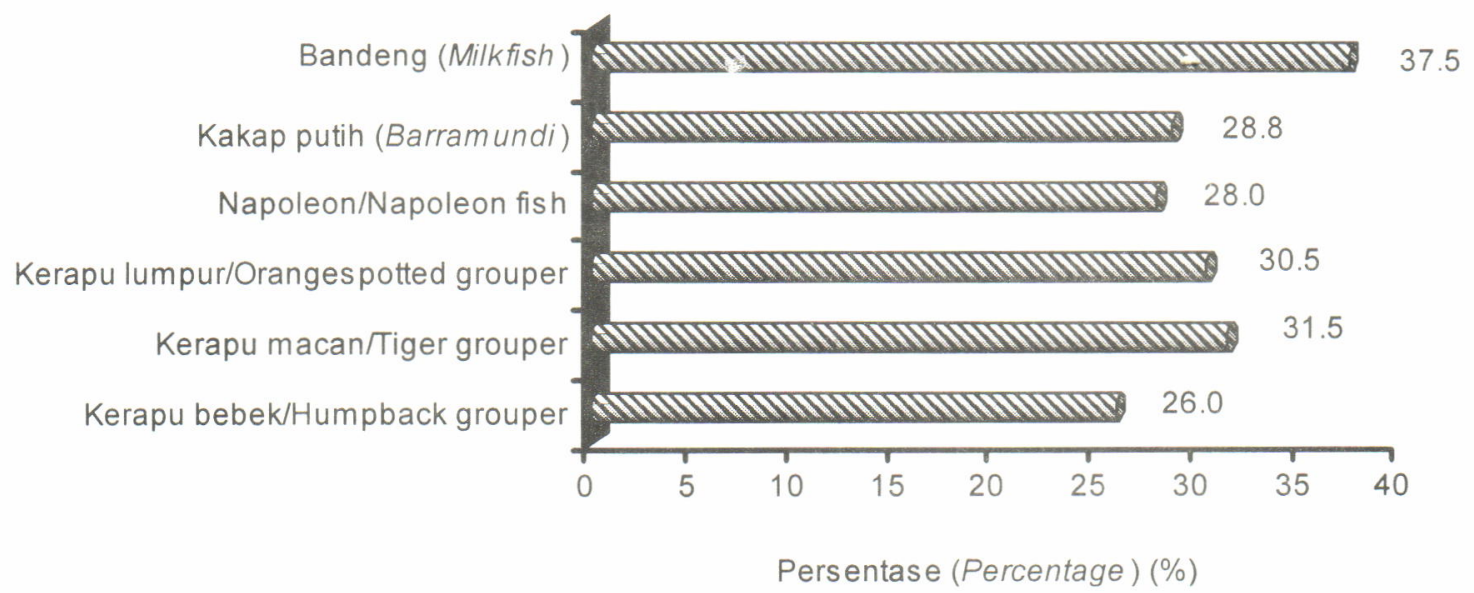

Gambar 1. Penetapan nilai hematokrit (PCV) beberapa jenis ikan budi daya laut

Figure 1. Hematocrit value (PCV) of several species of maricultured fish 


\section{Penetapan Kadar Hemoglobin $(\mathrm{Hb})$}

Hasil penetapan kadar hemoglobin beberapa jenis ikan budi daya laut disajikan pada Gambar 2. Pada ikan kakap putih kadar hemoglobin adalah sebesar $9,5 \mathrm{~g} / 100 \mathrm{~mL}$; ikan bandeng sebesar $8,5 \mathrm{~g} / 100 \mathrm{~mL}$; ikan kerapu macan sebesar $6,75 \mathrm{~g} / 100 \mathrm{~mL}$; ikan napoleon sebesar $6,5 \mathrm{~g} / 100 \mathrm{~mL}$; ikan kerapu lumpur; dan ikan kerapu bebek sebesar $6,25 \mathrm{~g} / 100 \mathrm{~mL}$. Sedangkan nilai penetapan kadar hemoglobin yang telah dilaporkan adalah pada ikan yellowtail sebesar $10,1 \mathrm{~g} / 100 \mathrm{~mL}$ (Ikeda et al., 1986). Pada ikan common carp sebesar 7,1--13,0 g/100 mL dan ikan rainbow trout sebesar 5,7--10,3 g/100 mL (Klontz, 1994).

Pada ikan kakap putih dan ikan bandeng kadar hemoglobin tampak lebih tinggi dibandingkan dengan ikan napoleon dan ikan kerapu. Hal ini dimungkinkan karena ikan kakap putih dan ikan bandeng dalam hidupnya selalu bergerak cepat, sehingga kebutuhan oksigennya sangat tinggi. Dengan tingginya hemoglobin, semakin banyak kemampuannya untuk mengikat oksigen dan mendistribusikannya dalam darah. Sedangkan ikan napoleon dan ikan kerapu merupakan ikan karang, yang dalam kehidupannya lebih banyak berdiam di karang-karang, sehingga kebutuhan oksigen dalam tubuh tidak terlalu tinggi. Hemoglobin berfungsi mengangkut oksigen, pada saat darah mengalir ke seluruh tubuh, hemoglobin melepaskan oksigen ke sel dan mengikat karbondioksida. Banyaknya oksigen yang diterima oleh jaringan tergantung pada kadar dan fungsi hemoglobin yang tersedia.

Tingkat kadar hemoglobin bisa dipakai sebagai petunjuk penting bagi tindakan medis selanjutnya. Penetapan kadar hemoglobin secara luas dilakukan dalam laboratorium karena pemeriksaan ini merupakan langkah esensial dalam pemeriksaan darah.

\section{Penghitungan Total Eritrosit}

Penghitungan total eritrosit yang diperoleh terlihat pada Gambar 3, yaitu berturut-turut pada ikan kerapu macan sebesar $3,35 \times 10^{6} \mathrm{sel} / \mathrm{mL}$; ikan bandeng sebesar $3,02 \times 10^{6} \mathrm{sel} / \mathrm{mL}$; ikan kerapu lumpur sebesar $2,97 \times 10^{6} \mathrm{sel} / \mathrm{mL}$; ikan kakap putih sebesar $2,87 \times 10^{6} \mathrm{sel} / \mathrm{mL}$; ikan napoleon sebesar $2,34 \times 10^{6}$ $\mathrm{sel} / \mathrm{mL}$; dan ikan kerapu sebesar $1,84 \times 10^{6} \mathrm{sel} / \mathrm{mL}$. Dari penghitungan total eritrosit ini, nilai yang terendah terlihat pada ikan kerapu bebek, namun masih dalam kisaran normal seperti yang dilaporkan oleh Ikeda et al., (1986) pada ikan yellowtail sebesar 3,03 $\times 10^{6}$ $\mathrm{sel} / \mathrm{mL}$. Pada ikan catfish sebesar $3,18 \times 10^{6} \mathrm{sel} / \mathrm{mL}$ (Chinabut et al., 1991); pada ikan common carp sebesar $0,84 \times 10^{6} \mathrm{sel} / \mathrm{mL}$; dan ikan rainbow trout sebesar $1,01 \times 10^{6} \mathrm{sel} / \mathrm{mL}$ (Klontz, 1994).

\section{Penghitungan Total Leukosit}

Dari Gambar 4, diketahui bahwa nilai total leukosit berturut-turut pada ikan kakap putih sebesar 183,5x $10^{3} \mathrm{sel} / \mathrm{mL}$; ikan bandeng sebesar $102,2 \times 10^{3} \mathrm{sel} /$ $\mathrm{mL}$; ikan napoleon sebesar $62,3 \times 10^{3} \mathrm{sel} / \mathrm{mL}$; ikan kerapu macan sebesar $57,6 \times 10^{3} \mathrm{sel} / \mathrm{mL}$; ikan kerapu lumpur sebesar $44,6 \times 10^{3} \mathrm{sel} / \mathrm{mL}$; dan ikan kerapu bebek sebesar $35,2 \times 10^{3} \mathrm{sel} / \mathrm{mL}$. Melihat hasil leukosit yang diperoleh pada Gambar 4, total leukosit masih berada dalam kisaran yang dilaporkan Ikeda et al. (1986) pada ikan yellowtail sebesar $46,55 \mathrm{x}$ $10^{3} \mathrm{se} / \mathrm{mL}$ dan pada ikan catfish sebesar $64,75 \mathrm{x}$ $10^{3} \mathrm{sel} / \mathrm{mL}$ (Chinabut et al., 1991).

Leukosit merupakan salah satu sel darah yang mempunyai peran sangat penting dalam sistem tanggap kebal ikan. Leukosit terbagi menjadi leukosit granular dan leukosit agranular berdasarkan ada tidaknya granul. Selanjutnya leukosit granular terdiri atas eosinofil, basofil, dan neutrofil, sedangkan

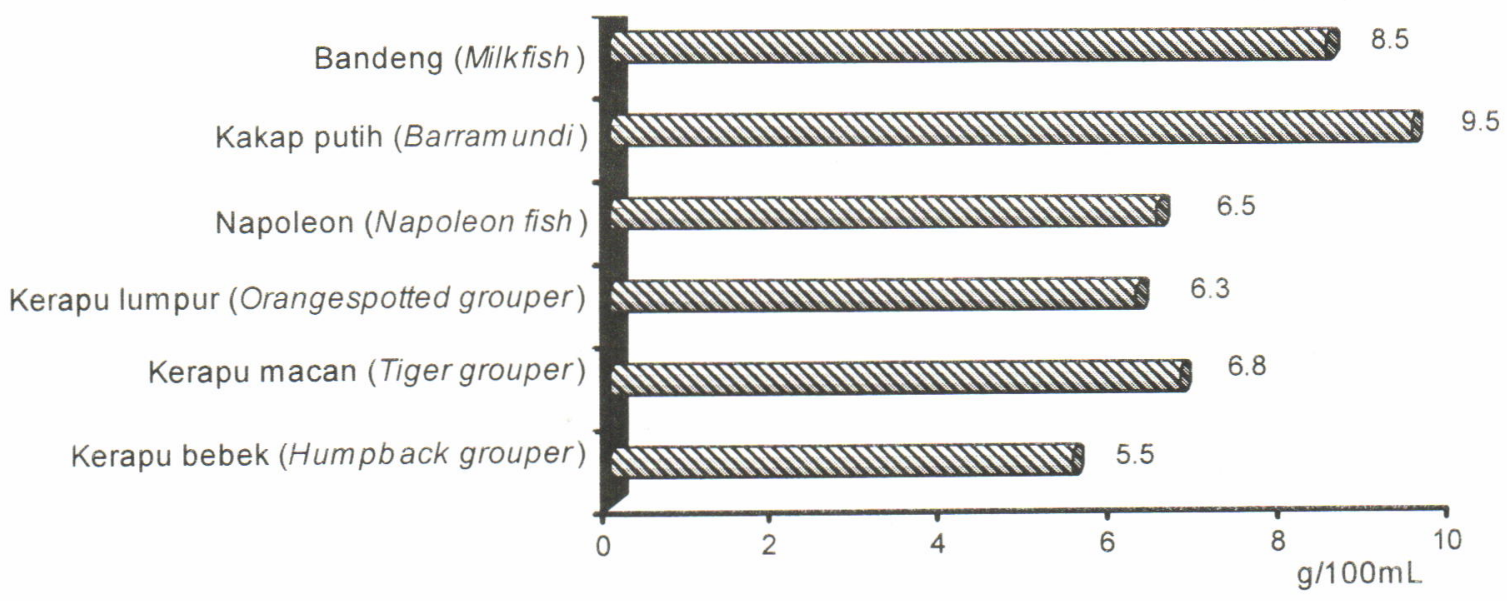

Gambar 2. Penetapan kadar hemoglobin $(\mathrm{Hb})$ beberapa jenis ikan budi daya laut

Figure 2. Hemoglobin value $(\mathrm{Hb})$ of several species of maricultured fish 


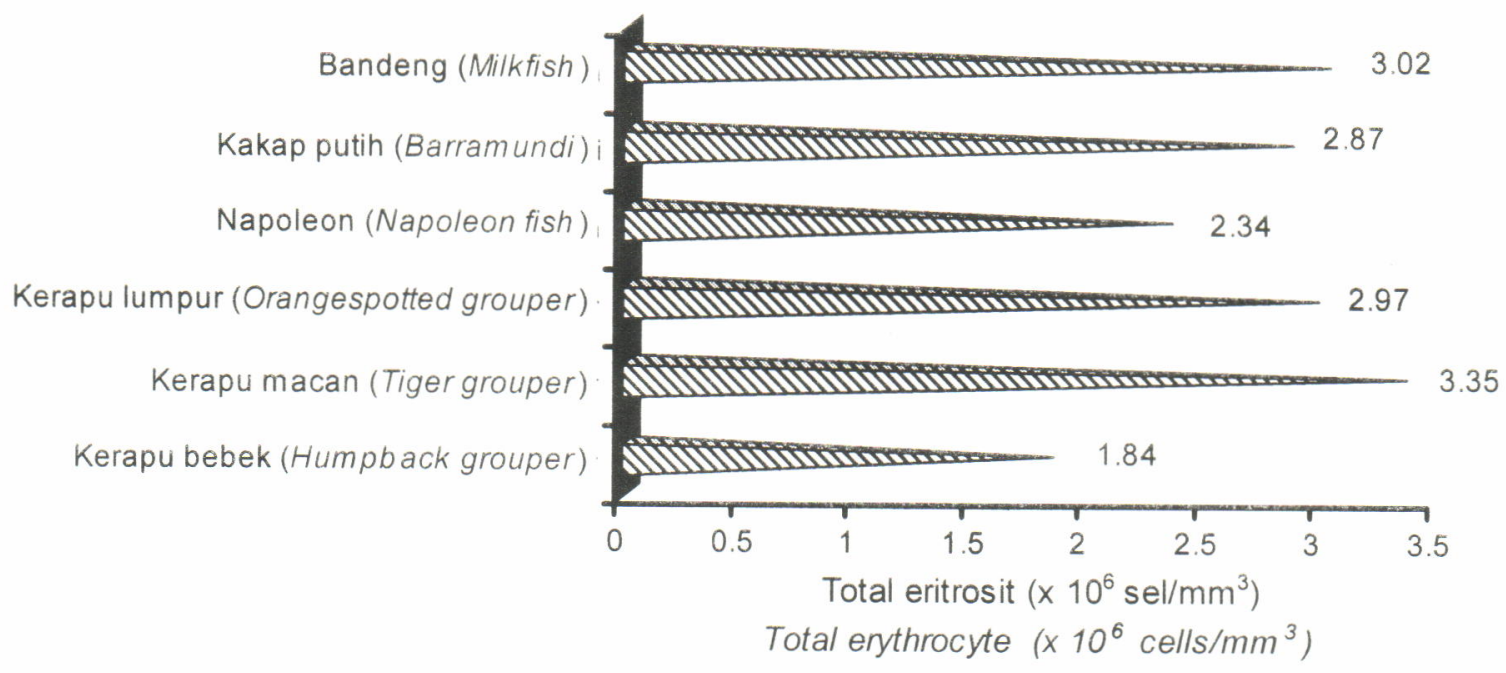

Gambar 3. Penghitungan total eritrosit beberapa jenis ikan budi daya laut

Figure 3. Total erythrocyte value of several species of maricultured fish

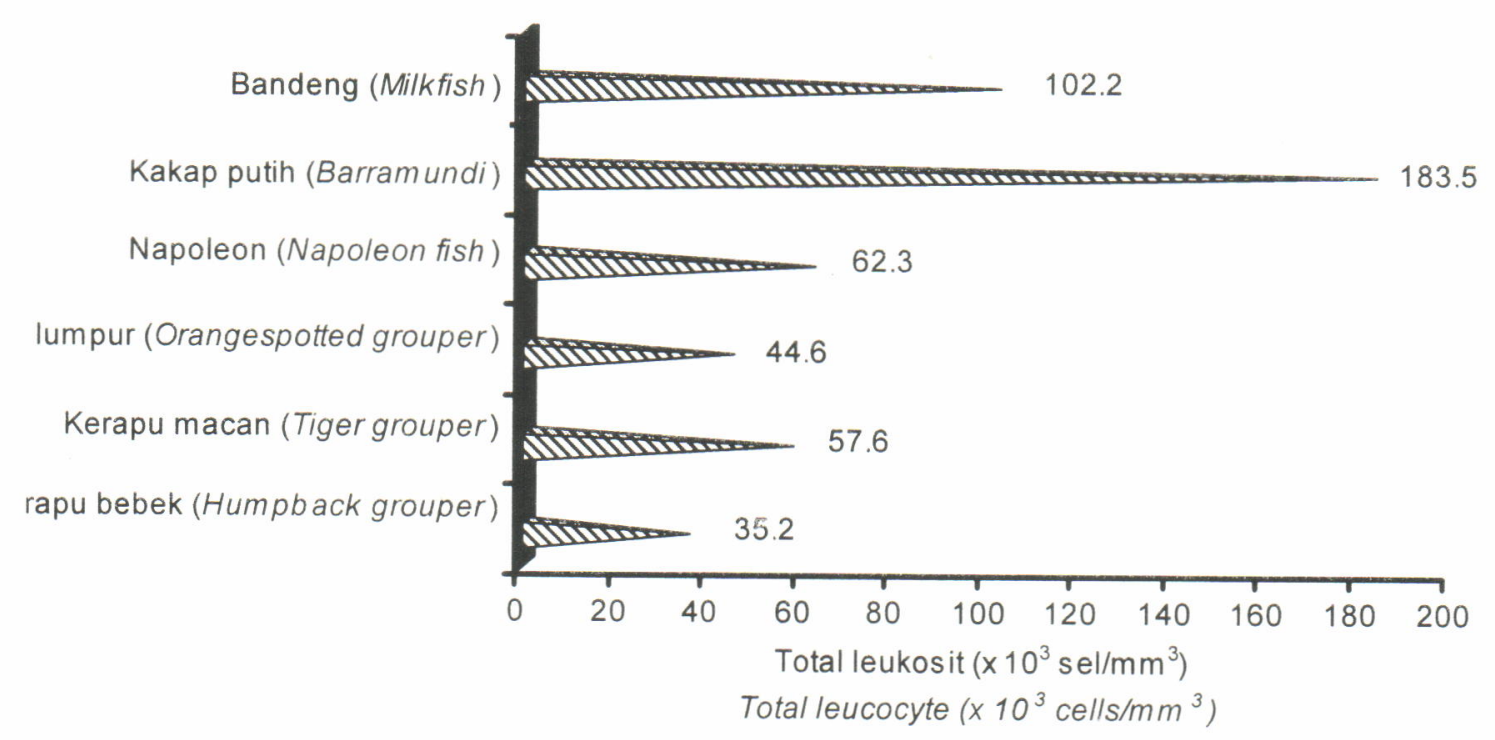

Gambar 4. Penghitungan total leukosit beberapa jenis ikan budi daya laut

Figure 4. Total leucocyte value of several species of maricultured fish

leukosit agranular terdiri atas monosit, limfofit, dan trombosit. Dalam beberapa laporan leukosit yang lazim ditemukan pada ikan adalah neutrofil, monosit, limfosit, dan trombosit. Leukosit sangat berbeda dari eritrosit karena memiliki kemampuan bergerak bebas, dan mampu keluar dari pembuluh darah menuju jaringan dalam melakukan fungsinya. Jumlah seluruh leukosit jauh di bawah eritrosit dan bervariasi tergantung jenis hewannya. Jumlah leukosit yang menyimpang dari keadaan normal mempunyai arti klinik penting dalam mengevaluasi gangguan kesehatan. Jumlah leukosit akan meningkat secara pesat dalam waktu yang singkat apabila terjadi suatu penyakit infeksi (Anderson, 1974; Tizard, 1982; Man- ning \& Tatner, 1985; Nabib \& Pasaribu, 1989; Iwama \& Nakanishi, 1996).

\section{Penghitungan Persentase Diferensial Leukosit}

Dari Gambar 5 diketahui bahwa persentase neutrofil yang diperoleh pada ikan kakap putih sebesar $8 \%$; ikan kerapu bebek sebesar 7,25; ikan napoleon sebesar $6,9 \%$; ikan bandeng sebesar $6.5 \%$; ikan kerapu macan sebesar $4,2 \%$; ikan kerapu lumpur sebesar $3,9 \%$. Nilai persentase diferensial neutrofil yang telah dilaporkan adalah sebesar $6 \%--8 \%$ (Anderson, 1974; Chinabut et al., 1991; Klontz, 1994). 
Neutrofil mempunyai bentuk agak lonjong atau bulat, protoplasma berwarna sedikit biru dan inti bersegmen, kadang-kadang berlobus. Fungsi utama neutrofil adalah penghancur bahan asing melalui proses fagositik dan merupakan garis pertahanan pertama yang bergerak cepat ke arah bahan asing dan menghancurkannya, tetapi tidak mampu bertahan lama. Umumnya jumlah neutrofil meningkat pada saat kasus penyakit bakteri karena neutrofil keluar dari pembuluh darah menuju daerah infeksi (Anderson, 1974; Tizard, 1982; Manning \& Tatner, 1985; Chinabut et al., 1991; Iwama \& Nakanishi, 1996).Persentase monosit yang diperoleh adalah pada ikan kerapu macan sebesar 2,5\%; ikan kerapu lumpur sebesar $2,1 \%$; ikan bandeng sebesar $1,9 \%$; ikan napoleon sebesar $1,8 \%$, ikan kakap putih sebesar $1,5 \%$; dan ikan kerapu bebek sebesar 1,3\%. Monosit mempunyai fungsi yang sama dengan makrofag (Anderson, 1974; Manning \& Tatner, 1985; Iwama \& Nakanishi, 1996). Tizard (1982) menyatakan bahwa makrofag dapat juga disebut sebagai monosit. Monosit merupakan sel yang besar, memiliki bentuk bervariasi, sering dijumpai adanya bentuk pseudopodia dan ditemukan mikrofili pada membran sitoplasma. Terkadang monosit sulit dibedakan dari limfosit yang lebih besar dan neutrofil yang belum matang. Monosit berfungsi sebagai makrofag dan memfagosit benda-benda asing yang masuk dalam tubuh. Fagositosis oleh monosit merupakan proses yang sama seperti pada neutrofil, akan tetapi monosit ini mampu memiliki aktivitas fagositik yang tahan lama. Proporsi monosit sangat rendah dalam populasi leukosit, akan tetapi dapat meningkat lebih $30 \%$ dalam waktu singkat apabila terjadi infeksi (Anderson, 1974; Tizard, 1982;
Manning \& Tatner, 1985; Chinabut et al., 1991; Iwama \& Nakanishi, 1996). Dalam percobaan ini, proporsi monosit berada dalam kisaran persentase diferensial yang telah dilaporkan sebesar $0,1 \%--3 \%$ (Anderson, 1974; Chinabut et al., 1991; Klontz, 1994).Besarnya pesentase limfosit diperoleh pada ikan napoleon sebesar 78,1\%; ikan kakap putih sebesar 75,0\%; ikan bandeng sebesar $72,4 \%$; ikan kerapu lumpur sebesar $71,2 \%$; ikan kerapu bebek sebesar $70,4 \%$; dan ikan kerapu macan sebesar $68,3 \%$. Nilai persentase diferensial limfosit masih berada dalam kisaran yang telah dilaporkan sebesar 60\%--80\% (Anderson, 1974; Chinabut et al., 1991; Klontz, 1994). Limfosit berbentuk bundar dengan inti berwarna ungu, kadangkadang tampak sedikit melekuk, dan sitoplasma terlihat sedikit berwarna biru. Limfosit berfungsi menyediakan zat kebal untuk pertahanan tubuh, ditemukan dalam jumlah yang besar meskipun pada saat infeksi terjadi penurunan (Anderson, 1974; Tizard, 1982; Chinabut et al., 1991; Brown, 1993; Klontz, 1994; Iwama \& Nakanishi, 1996).Nilai persentase trombosit berturut-turut adalah pada ikan kerapu macan sebesar $25 \%$; ikan kerapu lumpur sebesar $22,8 \%$; ikan kerapu bebek sebesar $21,1 \%$; ikan bandeng sebesar 19,2\%; dan ikan napoleon sebesar $13,2 \%$. Nilai persentase diferensial trombosit yang telah dilaporkan adalah sebesar 20\%--30\% (Anderson, 1974; Chinabut et al., 1991; Klontz, 1994). Trombosit dilaporkan memiliki bentuk yang bervariasi, yaitu memanjang, bulat, atau berbentuk gabungan (fusiform). Trombosit ikan merupakan sel yang kecil, inti berbentuk elips dan terletak di tengah sel, sitoplasma yang mengelilinginya berwarna biru (Manning \& Tatner, 1985; Moyle \& Cech, 1988; Chinabut

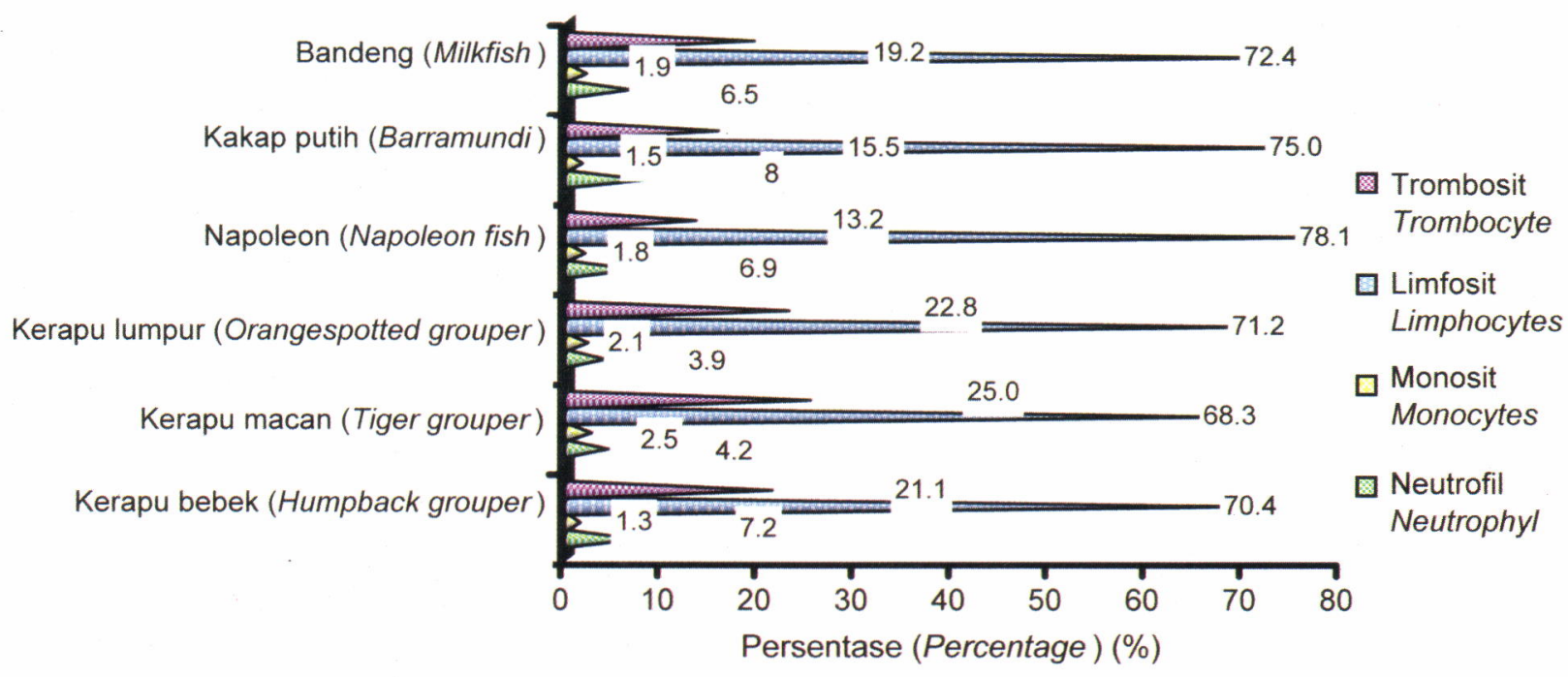

Gambar 5. Penghitungan persentase diferensial leukosit beberapa jenis ikan budi daya laut

Figure 5. Percentage value of differential leucocytes of several species of maricultured fish 


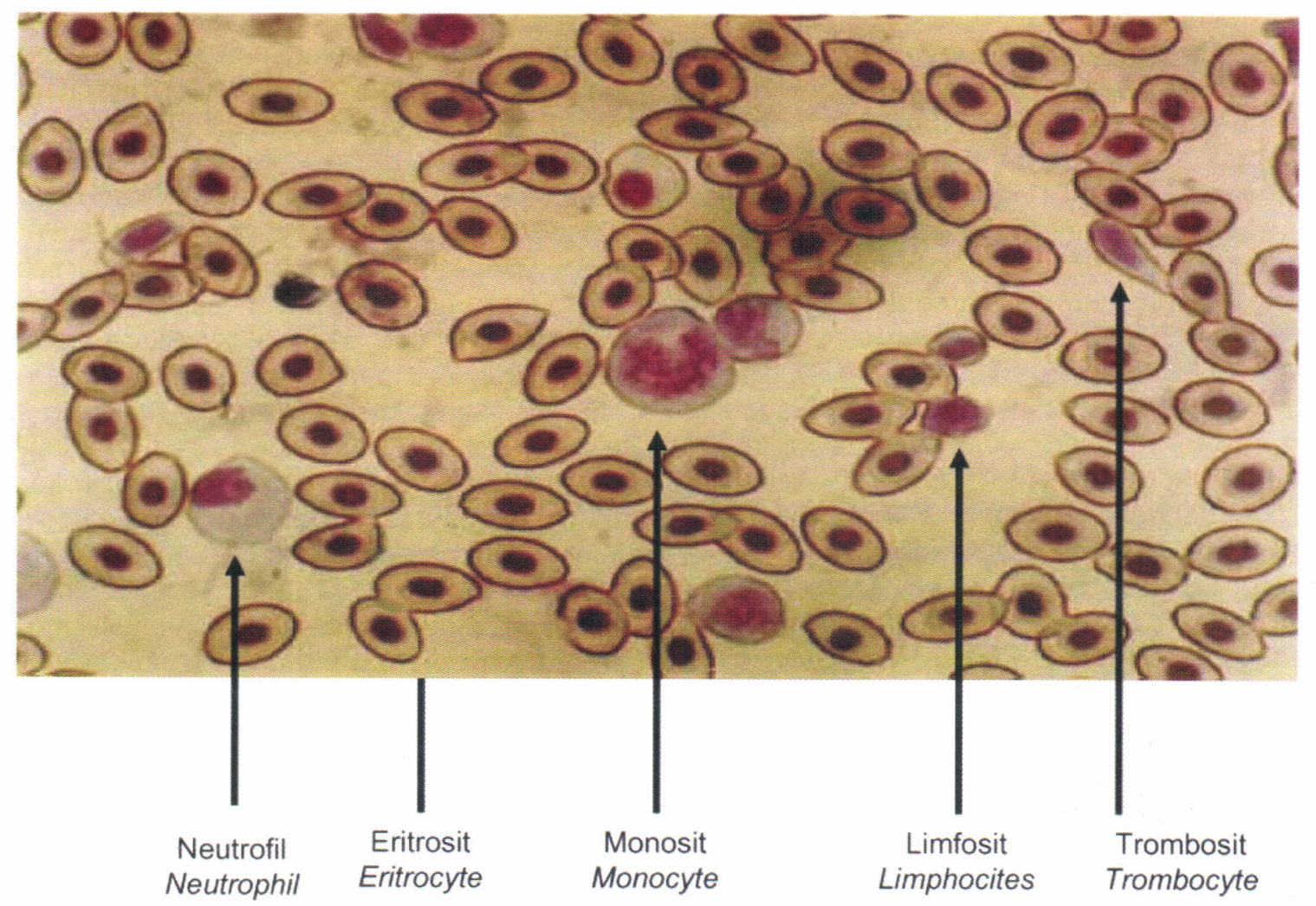

Gambar 6. Morfologis sel darah pada ikan laut budi daya Figure 6. Morphological blood cells on maricultured fish

et al., 1991). Fungsi utama trombosit sebagai penutup luka, jumlah trombosit umumnya meningkat setelah terjadi luka atau hemoragi (Manning \& Tatner, 1985; Chinabut et al., 1991; Iwama \& Nakanishi, 1996).

\section{KESIMPULAN}

Keragaan hematologis ikan laut budi daya berbeda antar spesies. Hasil percobaan menunjukkan nilai hematokrit tertinggi pada ikan bandeng sebesar 37,5\% dan terendah pada ikan kerapu bebek sebesar 26,0\%. Kadar hemoglobin tertinggi pada ikan kakap putih sebesar 9,5 g/100 mL dan terendah pada ikan kerapu bebek sebesar $5,5 \mathrm{~g} / 100 \mathrm{~mL}$. Total eritrosit tertinggi pada ikan kerapu macan sebesar 3,35 × $10^{6} \mathrm{sel} / \mathrm{mL}$, dan terendah pada ikan kerapu bebek sebesar 1,84 $\mathrm{x}$ $10^{6} \mathrm{sel} / \mathrm{mL}$. Total leukosit tertinggi pada ikan kakap putih sebesar $183,5 \times 10^{3} \mathrm{sel} / \mathrm{mL}$, dan terendah pada ikan kerapu bebek sebesar 35,2 × $10^{3} \mathrm{sel} / \mathrm{mL}$. Sedangkan untuk diferensial leukosit; persentase neutrofil tertinggi pada ikan kakap putih sebesar $8,0 \%$, dan terendah pada ikan kerapu Lumpur sebesar 3,9\%. Persentase monosit tertinggi pada ikan kerapu lumpur sebesar 2,5\% dan terendah pada ikan kerapu bebek sebesar 1,3\%. Persentase limfosit tertinggi pada ikan kerapu lumpur sebesar $25,0 \%$ dan terendah pada ikan napoleon sebesar 13,2\%. Persentase trombosit tertinggi pada ikan napoleon sebesar 78,1\% dan terendah pada ikan kerapu lumpur sebesar $68,3 \%$.

\section{DAFTAR PUSTAKA}

Anderson, D.P. 1974. Fish Immunology. T.F.H. Publication Inc. Ltd. U.S.A. 239 pp.

Andrew, C., A. Exell, and N. Carrington. 1988. The Manual of Fish Health. Salamander Books Ltd. United Kingdom. 208 pp.

Anderson, D.P. and A.K. Siwicki. 1995. Basic haematology and serology for fish health programs. In Diseases in Asian Aquaculture II. M. Syariff, J.R. Arthur, dan R.P. Subasinghe (Eds.), Fish Health Section. Asian Fisheries Society. Manila. Philippines. p.185--202.

Bastiawan, D.A. Wahid, M. Alifudin, dan I. Agustiawan. 2001. Gambaran darah lele dumbo (Clarias spp.) yang diinfeksi cendawan Aphanomyces spp. pada pH yang berbeda. J. Pen. Per. Indonesia. 7(3): 44-61.

Brown, L. 1993. Aquaculture for Veterinarians: Fish Husbandry and Medicine. Pergamon Press Ltd. USA. 447 pp.

Chinabut, S., C. Limsuwan, and P. Kitsawat. 1991. Histology of the Walking Catfish, Clarias batrachus. AAHRI. Bangkok. Thailand. 96 pp. 
Filho, D.W., G.J. Eble, G. Kassner, F.X. Caprario, A.L. Dafre, and $M$. Ohira. 1992. Comparative hematology in marine fish. Comp. Biochem. Physiol. A. 102A(2): 311--321

Ikeda, Y., O. Kunio, and K. Hisao. 1986. Blood Atlas of fishes. (In Japanese). Tokyo. p. 242--243.

Iwama, G. and T. Nakanishi. 1996. The Fish Immune System. Academic Press, Inc. USA. 380 pp.

Johnny, F., Zafran, D. Roza, I. Koesharyani, dan K. Yuasa. 1999. Morfologi dan karakteristik hematologi ikan kerapu bebek, Cromileptes altivelis. Dipresentasikan pada Seminar Nasional ke-3 Penyakit Ikan dan Udang, Yogyakarta, 8--9 November 1999. 11 pp.

Johnny, F. D. Roza, dan B. Slamet. 2001. Karakteristik dan morfologi darah ikan napoleon, Cheillinus undulatus. Prosiding Simposium Pemuliaan VI; Kontribusi Pemuliaan dalam Inovasi Teknologi Ramah Lingkungan Dalam Kasno et al. (Eds.), Bandung; Perhimpunan IImu Pemuliaan Indonesia. p. 140--143.

Johnny, F. 2002. Gambaran hetamologi ikan kakap putih, Lates calcalifer Bloch. Dipresentasi pada Seminar Nasional Biologi XVII, Universitas Andalas, Padang 22--24 Juli 2002. 12 pp.

Johnny, F. dan D. Roza. 2002. Kejadian penyakit pada ikan budi daya laut dan upaya penanggulangannya. Makalah Dipresentasikan pada Lustrum ke-1 FKHUniversitas Udayana pada tanggal 7 November 2002. $12 \mathrm{pp}$.

Johnny, F., Zafran, D. Roza, dan I.N.A. Giri. 2002. Pengaruh vitamin $C$ dalam pakan terhadap perubahan hemositologi ikan kerapu bebek, Cromileptes altivelis. Aquaculture Indonesia. 3(1): 27--34.

Klontz, G.W. 1994. Fish hematology. In Stolen et al. (Eds.). Techniques in Fish Immunology-3. Sos Pub- lications, Fair Haven, NJ 07704-3303. USA. p. 121131.

Manning, M.J. and M.F. Tatner. 1985. Fish Immunology. Academic Press Inc. London. 369 pp.

Moyle, P.B. and J.J. Cech. 1988. Fishes and Introduction to Ichthyology. Second edition. Prentice-Hall, Inc. New Jersey. 559 pp.

Nabib, R. dan F.H. Pasaribu. 1989. Bahan Pengajaran Patologi dan Penyakit Ikan. Dept. P\&K. Ditjen. Pendidikan Tinggi. PAU Bioteknologi-IPB. Bogor. 158 $\mathrm{pp}$.

Post, G. 1987. Texbook of Fish Health. T.F.H. Publications Inc. USA. $288 \mathrm{pp}$

Schalm, O.W., N.C. Jain, and E.J. Carroll. 1975. Veterinary Hematology. $3^{\text {rd }}$ Edition. Lea \& Fehiger. Philadelphia. 807 pp.

Schubert, G. 1987. Fish Diseases a Complete Introduction. T.F.H. Publications Inc. USA. 125 pp.

Singh, S. and V. Banerjee. 1992. Hematology of the marine fish Leptorocanthus savala (Cuv.). Environ-Ecol. 10(4): 985--987.

Sukadi, F. 2002. Peluang dan tantangan bisnis akuakultur di Indonesia pada era globalisasi. Makalah pada Seminar Nasional Masyarakat Akuakultur Indonesia di Hotel Sahid Surabaya, pada tanggal 30 Oktober 2002. 12 pp.

Tizard, I. 1982. Pengantar Immunologi Veteriner. Terjemahan Partodiredjo et al., 1988. Airlangga University Press. $497 \mathrm{pp}$.

Tochilina, L.V. 1992. Summer hematologic characteristics of marine fishes. Hydrobiol-J. 28(4): 40--44.

Yamamoto, A. and T. lida. 1994. Hematological characteristics of triploid rainbow trout. Fish Pathology. 29(4): 239--243. 